\title{
THE USE OF BOOK STORY IN TEACHING READING COMPREHENSION
}

\author{
Ivan Ferdiana Syarief ${ }^{1}$, Yanuarti Apsari ${ }^{2}$, Arsy Nastiti Karya Dewi ${ }^{3}$ \\ ${ }^{1}$ IKIP Siliwangi \\ ${ }^{2}$ IKIP Siliwangi \\ ${ }^{3}$ IKIP Siliwangi \\ ${ }^{1}$ ivan.ferdianas25@gmail.com, ${ }^{2}$ yanuar.apsari1@gmail.com, ${ }^{3}$ arsynkd@gmail.com
}

\begin{abstract}
In general, students' difficulties in understanding of reading is in expressing the meaning and purpose of the reading. The researcher found these problem while conducting research at one of the Islamic Schools in class VIII at SMP PLUS YPP DARUSSURUR CIMAHI. This study aims to improve the reading ability of students through English-language storybook media. This research used Classroom Action Research design which includes planning, action, observation, reflection or evaluation activities. The study was conducted SMP PLUS YPP DARUSSURUR CIMAHI. The sample of the research is class VIII C that contain of 26 students. The results showed that before treatment was given using the English-language storybook media, after reading comprehension learning using English-language book story at the first cycle the average value of reading comprehension skills of students increased still in the medium category In cycle 1, the researcher discover that $70 \%$ or 18 out of 26 students got the score under KKM, and learning was done on the second cycle was found that $86.20 \%$ of the students or 25 out of 26 students got the score more than or equal to 70 related to the Minimum Mastery Criteria of reading comprehension ability of students experienced an increase in average value with a very high category.
\end{abstract}

Keywords: Reading, Media Story Books, CAR

\section{INTRODUCTION}

Language is the most important aspect in human interaction. People communicate and interact with others by using the language. One of many international language that used in Indonesia is English language. English language become an international language because many region or states that uses English language as communication. English is a tool for communicating both spoken and written. Thus, English serves as a communication tool in order to access information as well as a tool for fostering interpersonal relationships, exchanging information and enjoying language aesthetics in British culture. Therefore, English subjects aim as follows :1) Develop the ability to communicate in English, either in oral or written form, which includes listening, speaking, reading and writing. ; 2) Growing awareness of the nature of language and the importance of English as a foreign language to become the main tool of learning. ; 3) Develop an understanding of the interrelationships between languages and cultures and broaden cultural horizons so that students have cross-cultural insights and can involve themselves in cultural diversity.

There are four major skills in learning English languge. One of them is reading. Reading is an activity informed by the apprehension of images, shapes, patterns, and rhythms, which come to be recognized through repeated encounters and remembered forms; the meanings that are made in reading are in excess of the meanings that arise from the interpretation of written language 
(Lorange, 2014: 30) as cited in Parmawati (2018). Reading comprehension is important in learning English Language. Acccording to Alyousef (2006:64) in Andi Herdiana Nur (2017), reading can be seen as an "interactive" process between a reader and a text which leads to automaticity or (reading fluency). This statement is supported by River (1996) in Manan (2017), "reading is the most important activities in language class, not only as source information and extending one's knowledge." Reading comprehension is a process in understanding the contents of the reading, for which a solution is needed as a solution that can at least reduce the difficulties of students in reading various kinds of English textbooks.

Through the results of the preliminary analysis and questionnaire of interest and reading habits, there are found some problems that faced by students in learning English. One of major problem that needs attention is students reading enthusiate. The interest in reading English texts of students is still very low, the results of student learning in English in general also shows low. From the finding above, it can be concluded that students' interest can affect the quality of teaching and learning process as explained by Leipzig (2001) in (Frimasary (2015), that Reading is a multifaceted process involving word recognition, comprehension, fluency, and motivation, It learn how readers integrate these facets to make meaning from the printed materials. For general, reading comprehension its most obvious sense, the ability to understand information in a text and interpret it appropriately. In addition, Chair (2002:11) in Megawati (2017)said that Reading comprehension is the process of constructing meaning involving the written language by interpreting textual information in the light of prior knowledge and experiences using appropriate and efficiency comprehension strategies. As stated by Silver (1997) in Apsari (2014)that there is a high correlation between those who read a lot and those who improve in their comprehension and vocabulary acquisition when they read. Thus, the teacher should provide the students' preferable text in order to encourage them to keep reading. From the definition above, researcher conclude that reading comprehension is importtant for the students to get understanding in learning English language becasue reading comprehension can be defined as the process in which the reader construct meaning from a text connected to the background knowledge they have get the clear understanding of the writer's message.

In order to solve the problem, the researcher wants to apply an interractive teaching method to increase students' interest in reading. Therefore, in teaching reading can be done through some ways or techniques to create a good atmosphere and interesting during the learning process. One of them is by implementing English short story. The aim is easy to understand by the students, and also can be developed any kind of teaching material so that the reading learning will not become monotonous and boring. The researcher apply the teaching activity by using StoryBook media. Storybook media can be used to improve the ability to read students. Some expert has same statement about this. According to Liu (2004: 226) in Wahyu Nugroho (2017), many reading comprehension studies consider the extent to which visuals, that is any graphic display that portrays all or some accompanying text's content, help reader to comprehend factual information. This statement is supported by another expert, Ghasemi and Hajizadeh (2011) in Pransiska (2018) that the short stories have the unique characteristics thus making the learners especially suitable to be used in reading comprehension. In addition, with the existence of this storybook media, it hopes to be able to provide reading interest and have a positive impact on students through their characteristics that an in make readers feel happy. Children's interest in storytelling gives meaning to the need to use storybook media for learning. The use of storybook media is expected to help students develop language skills, art, and assist students in interpreting and recalling stories that are in it. In the field of literature, storybook media can 
give encouragement to students to read, build vocabulary vocabulary, and provide guidance and train students to express themselves with the help of visual forms in story books.

The researcher using short story because in teenagers' level, short story is the most interested literary work to read. It because short story not too long to read and has various interesting topics. So hopefully through this way, they can improve their comprehension in reading without boredom.

\section{METHOD}

This research design used Classroom Action Research (CAR). Burns (2010: 2) in Ningtyas Orilina Argawati (n.d.) suggests that action research is part of abroad movement that has been going on in education generally for some time and related to the ideas of "reflective practice" and "the teacher as researcher", which includes planning activities (planning), action (action), observation (observation), and reflection.

Each cycle is carried out according to the changes that occur in students as they have been designed on the factors investigated (student factors), to determine the ability to understand the contents of English reading VIII grade students at PLUS YPP DARUSSURUR CIMAH Middle School, students are given a pre-cycle test without given reading learning using storybook media. Furthermore, at the stage per cycle during learning students are given treatment that is learning the ability to read comprehension using storybook media. In the first cycle, the story book used is a story book with colorless images. The second cycle of the English-language storybook used is a colored English storybook. The English storybook media used is a learning storybook media that is designed and developed through research and media expert validation tests, languages, and contents. Learning to read understanding English using media story books is done in two cycles four times face to face. Time allocation used every cycle for $2 \times 40$ minutes per one time face-to-face learning. If the results of the second cycle test are considered incomplete, the research will continue to the next cycle. The procedure for implementing classroom action research is carried out through the stages of planning, action, observation (observation), and reflection (reflection). The four stages take place repeatedly in the form of cycles, namely (1) the planning stage, including (a) analyzing and studying the English syllabus used by the teacher at YPP DARUSSURUR CIMAH PLUS, (b) compiling a lesson plan by applying learning media namely English-language storybook media, (c) designing and conditioning classes during classical learning, (d) discussing the application of interactive learning, (e) compiling research instruments (interest tests and reading habits, pre-test, observation sheet, and the final test of reading comprehension), (f) composing learners' groups; and (g) planning group assignments if needed; (2) the stage of action (action), including (a) preliminary activities, (b) core activities, and (c) closing activities; (3) observation stage (observation), including (a) collaborating with English teachers to carry out observation activities during the implementation of reading learning with English-language storybook media, (b) recording every finding from students during the reading learning process of understanding with storybook media speak English, (c) discuss with English teachers after completion of learning to convey weaknesses, shortcomings, and findings during the implementation of reading comprehension learning with English-language storybook media(4) reflection, including (a) analyzing weaknesses, shortcomings, and findings during the implementation of reading comprehension learning with the English-language comic media, (b) conducting discussions with English teachers to plan further activities about weaknesses, shortcomings, and findings found during the implementation of learning, (c) reflecting on observations from both the students and the teacher, and (d) rearranging the learning 
improvement plan to be carried out at the next meeting and cycle if the results have not reached the target as in the indicator of success in this research. The indicator of success in class action research refers to the Minimum Completion Criteria (KKM) of English subjects set by PLUS YPP DARUSSURUR CIMAHI Middle School, which is 70 as individual completeness. Increasing the value of the success of reading comprehension of English in classical students reaches $\geq 75 \%$ of students who get a value of $\geq 70$.

\section{RESULTS AND DISCUSSION}

\section{Results}

The problems encountered by the students actually touched all of English skills and components. However, after doing through observation and interview with the English teacher and the students, the researcher finally pointed that students' reading interest as the core problem to be solved. The students' found it was difficult to understand amd stay enjoy everything related to English.

Yet, unluckily, they found that English was difficult. Therefore, the researcher intended to conduct the research to afford an improvement for their English proficiency, especially for their interest on reading

Table 1. Schedule activity

\begin{tabular}{ccc}
\hline Meeting & Topic & Activities \\
\hline 1. & Pretest & Give student pre test reading. \\
\hline 2. & $\begin{array}{c}\text { Treatment I } \\
\text { (cycle I) }\end{array}$ & $\begin{array}{c}\text { Viewing story by slideshow during teaching } \\
\text { learning activity. }\end{array}$ \\
\hline 3. & $\begin{array}{c}\text { Treatment II } \\
\text { (cycle I) }\end{array}$ & Post reading activity. \\
\hline 4. & Post test & Give student test reading. \\
\hline 5. & $\begin{array}{c}\text { Treatment I } \\
\text { (cycle II) }\end{array}$ & Same as cycle I but with video. \\
\hline 6. & $\begin{array}{c}\text { Treatment II } \\
\text { (cycle II) }\end{array}$ & Post reading activity and sharing. \\
\hline 7. & Post test & Give student post test reading \\
\hline
\end{tabular}

The KKM was designed that the students could pass the test if they got score $\geq 70$. Due to the study is in the form of CAR, the findings could be seen from the cycles. In cycle 1, the researcher discover that $70 \%$ or 18 out of 26 students got the score under KKM. It was not given good results in increasing student mastery. Hence, planning in Cycle-1 requires to be repaired so that the next cycle can achieve the success criteria. From the explanation above, the researcher analyzed that there were several problems in the Cycle - 1 . That was the post test 1 score has not reach the criteria of success, students still had difficulty focusing on learning English, and so on.

Based on the above weaknesses, several revisions are made to be implemented in Cycle-2:a) The researcher give the text for a student, not for a group. So, each student got the different text, b) The researcher directly distributes the form (a special form for the reading assessment) for each student in each group, c) The researcher asks students to fill out forms based on what 
they have written in their books, d) The researcher shares the dictionary into the group. Each group gets a dictionary to check the meaning of the selected word, e) The researcher instructs the class to sit in their own chair to get a post-test, f) The Researchers provide shorter explanations and instructions, g) Post-tests use bilingual language in direct papers (EnglishIndonesian).

For the researcher, it was really helpful to improve students' understanding of the test points. This can be seen from the results of post-test 1 which the students cannot reach the KKM because lack of interest on reading. Therefore, the researcher tried to apply the story books as media by using bilingual language only on posttest. It is expected that students can understand the sentence points and complete the test briefly. Furthermore, the revisions of Cycle- 1 have been applied in the Cycle-2. It was found that $86.20 \%$ of the students or 25 out of 26 students got the score more than or equal to 70 related to the Minimum Mastery Criteria. It has given good result in improving students' vocabulary mastery. Therefore, it could be concluded that the planning in the Cycle -2 was implemented successfully.

From the statement above, the researcher analyzed that almost the problems in the Cycle -1 can be corrected in the Cycle- 2. The students' scores in the Post-Test 2 could reach the criteria. The students involved themselves in learning English, the students received the materials in which the teacher uses on that days, and so on. On the basis of the good results in the Post-Test 2 , the researcher did not need to continue the research.

\section{Discussion}

The initial results of reading comprehension ability of class VIII students of PLUS YPP Middle School DARUSSURUR CIMAHI are still very low when viewed from the Criteria for Minimum Completion of students' English learning outcomes. This can be seen from the reading comprehension ability test (pre-action) with the discourse text entitled "How to make egg and lemon soup" which was followed by all students, namely 26 students, obtained an average value of 62.70 with the highest score of 80 and the lowest score 45 . The number of students who scored according to the KKM was 15 students (57.70\%), and students who scored under the KKM were 11 students $(42.30 \%)$. The value obtained by students is an illustration of the ability to read pre-action student comprehension obtained by an average of $62.70(57.70 \%)$ with a medium category.

The first cycle of learning activities of the teacher began to use comic media in English and used an English language discourse sheet entitled "Sura and Baya". For about 50 minutes the teacher began reviewing reading comprehension lessons using English-language comic media. Students are asked to recite the pronunciation of the words in the content of the comic story and together read the comic story texts in English. Before students give a response, first be given the opportunity to students to tell what the story events in the comic even though students have not read the whole story in the comic, with the hope that students can understand the contents of the discourse just by looking at pictures in the comic. The teacher gives praise to students who raise their hands and convey what the teacher asks for even though students still feel hesitant. This opportunity makes other students nod off indicating that they understand what their friends are saying, even in Indonesian. After reading comprehension learning using English-language comic media the first cycle of students is given an understanding reading test and the average value of reading comprehension ability of students increases to $70(69.23 \%)$, the results are still in the moderate category. 
Based on the results and findings of the first cycle, further improvements and planning were carried out for action in the second cycle. During the implementation of the learning activities in the second cycle the teacher explained to students about reading lessons in English-language understanding using English-language comic media with colorful pictures, the teacher also conveyed the contents / topics of the comic story. Then students are asked to discuss discussing the topic of the English-language comic story text by searching for extensive information about the topic or theme of the story. Collaborators occasionally give direction to English teachers to guide the interaction between students and teachers, the environment, and oversee the involvement of students who are active in each learning activity. After the learning is complete, proceed with a question and answer session about the contents of the comic. The teacher gives the opportunity for students to retell the contents of the stories in the comic both verbally and in writing the ability to read comprehension students experience an increase in the average value and percentage of $81.54(88.46 \%)$ in the very high category.

The ability to read the understanding of class VIII C SMP PLUS YPP Darussurur students has increased from each cycle. Besides that, the teacher while learning English using the Englishlanguage comic media seemed able to make the learning atmosphere of reading comprehension in the classroom become active, interactive and fun. In accordance with the planning of classroom action research carried out in two cycles with four times face-to-face, and the results obtained were in accordance with the target.

\section{CONCLUSION}

From the results of research and discussion it was concluded that learning to read understanding of English by using comic media can improve abilities read the understanding of the SMP PLUS YPP DARUSSURUR Middle School students in the first cycle increased to $70(69.23 \%)$ still in the category is being Learning outcomes in the second cycle reading comprehension skills students experience increase in average value and percentage by 81.54 $(88.46 \%)$ in the very high category. Suggestions that researchers can convey first, for students students should be accustomed to reading and look for examples of concrete text, as well as experience new so that it will make trained and enjoy reading especially in the text English. Second, the teacher should play the role as the facilitator can make students more independent in learn. Teachers are more skilled and able to use interesting methods and learning media because proven using comic methods and media in learning can improve ability reading students' understanding especially in English learning. Third, schools should be obligatory the teachers in each classroom learning using learning media as an alternative in improving student learning outcomes at SMP PLUS DARUSSURUR CIMAHI .

\section{ACKNOWLEDGMENTS}

This project was supported by IKIP Siliwangi Bandung, certainly for English Education Study Programe lecturers'. The researcher are thankful to the Lecture, Mrs. Yanuarti Apsari for guiding the researcher until finished the project, and provided expertise that greatly assisted the research. Although they may not agree with all of the interpretations provided in this paper. The researcher is also grateful to family and friends for praying and motivate the researcher to finish the study at IKIP Siliwangi Bandung. The writer hope this journal could be helpful to reader or other researcher in the future. 


\section{REFERENCES}

Apsari, Y. (2014). The Use Of Authentic Materials In Teaching Reading Comprehension. Eltin Journal, Journal Of English Language Teaching In Indonesia, 2(2).

Frimasary, Amelia Eka. 2015. "Using Short Story To Improve Student's Reading Comprehension." 2(2).

Herdiana Nur, Andi \& Ahmad, Djuwairiah. 2017. "Interactive Approach At The First Grade."

Manan, Abdul \&. Hasbaini. 2017. "Teaching Reading Comprehension By Using Short Stories." English Education Journal 404-23.

Megawati. 2017. "The Improving Students' Reading Comprehension Through Grammar Translation Method." 95-108.

Orilina Argawati, N. N.D. "Capability On Understanding Grammar On The Second Semester."

Parmawati, A. (2018). The Study Correlation Between Reading Habit And Pronunciation Ability At The Second Grade Students Of Ikip Siliwangi. Eltin Journal, Journal Of English Language Teaching In Indonesia, 6(1), 46-52.

Pransiska, Tiara Eka. 2018. "The Use Of Short Story As Materials In Reading Comprehension In Mts Yapi Pakem Sleman Yogyakarta Grade Ix."

Wahyu Nugroho, Agung. 2017. "The Effectiveness Of Teaching Reading Using Comic Strip To Facilitate Students 'Reading Comprehension On Narrative Text." 